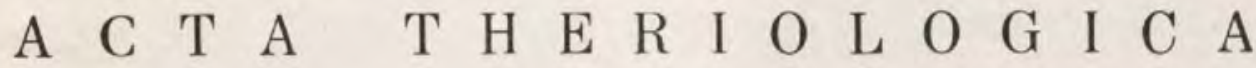

\section{The Eiiect of Reduced Calcium Level in Blood Serum on the Morphological Picture of the Adrenal Glands of the White Rat}

\author{
Wpływ obniżonégo poziomu wapnia w surowicy krwi na ohraz \\ moriologiczny nadnerczy szczura bialego
}

[With 2 Plates]

\section{INTRODUCTION}

The connection between adrenal and parathyroid glands has interested research workers for many years now.

Eppinger et al. (1908) suggested that there is an antagonistic activity between the adrenal and parathyroid glands. A large number of papers were published in the years following the above, supporting the theory of the antagonism taking place

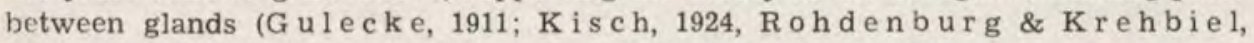
1925; Ta y lor \& Caven, 1927; Rog off \& Steward, 1928).

Harrop et al. (1933) and Grollman (1936), on the other hand, consider that there are no functional connections at all between the adrenal cortex and the parathyroid glands. The above authors examined the problems of interdependence of the adrenal and parathyroid glands, limiting themselves to chemical research (determination of the calcium and phosphorus levels in blood serums).

In $1953 \mathrm{Eg}$ e r observed increased functional strain on the adrenal gland after removal of the parathyroid glands. Atrophy of the lipoids took place in the cortex of these glands.

Recent reports explain with a greater degree of exactitude the connection between the glands discussed.

$\mathrm{Sallis} \& \mathrm{Holdsw}$ orth (1962) state that so far the question of the effect of hormones of the adrenal cortex on the metabolism of other cations than sodium and potassium has not been examined. These authors showed that the administration of $\Delta^{\prime}$ cortisol (glucocorticoid) causes a rise in the level of calcium in the blood serum. 
Menozzi et al. (1963) observed, after giving white rats cortisol, the occurrence in the bases of the long bones of osteoporosis fibrosa generalisata.

Forsh am (1963) found resorption of calcium from the bone to the blood after administering hormones from the glucocorticoid group. These latter papers indicate that the adrenal glands may affect the calcium economy of the animal system.

We were interested in the question of the effect of calcium contents in the blood on the picture of the adrenal cortex. In the literature available we found only a few morphological papers concerned with the changes taking place in the adrenal cortex under the influence of changed calcium level in blood serum. It was for this reason that we undertook work on this problem and made the following two experiments:

Experiment 1 consisted in the observation of changes taking place in the adrenal cortex after previous removal of the parathyroid glands, causing reduction of the calcium level in the blood serum.

Experiment 2 consisted in observation of the adrenal cortex after the calcium level in the blood serum had been reduced by intravenous injection of sodium oxalate.

\section{MATERIAL AND METHODS}

A total of 56 sexually mature male white rats, weighing about $200 \mathrm{~g}$, were used for the experiment. The animals were fed with the standard granulated diet obtained from the Institute of Medicines in Warsaw.

The animals were divided into three groups:

Group I - control animals - 10 rats

Group II - animals from which the parathyroid glands were removed by operation -30 rats

Group III - animals which were injected with $0.1 \mathrm{M}$. solution of sodium oxalate, with dosage of $1.6 \mathrm{ml}$ per $200 \mathrm{~g}$ of weight of the animal per day -16 rats.

Removal of the parathyroid glands by operation is difficult. In the first period of the experiment the parathyroid glands were removed from the animals together with the tissue surrounding the thyroid gland, which caused frequent haemorrhages from arteria thyroidea superior. On this account in our later operations, after the parathyroid glands had been revealed, they were held by forceps and the stem of the parathyroid gland ligatured, next excising the parenchyma of the gland in its entirety. Clinical symptoms of malfunction of the parathyroid glands occurred with uniform intensity after both the types of operation described. Sodium oxalate was injected into the marginal veins of the rats' tails (B ensley, 1947; Dzier ży$\mathrm{kray}-\mathrm{R}$ og a $1 \mathrm{ska}, 1958$ ). In order to facilitate access to the blood vessel, the rat's tail was illuminated from the bottom by a strong light through a narrov slit in a glass table specially constructed for this purpose. The rate of injection was e. $2 \mathrm{ml}$ of $0.1 \mathrm{M}$. solution of sodium oxalate per minute.

After the injections of sodium oxalate the animals exhibited extremely marked symptoms of tetanus.

Before the animals had been killed blood was taken by means of cardiac puncture, in order to define the calcium contents in the blood serum. The calcium level was calculated by means of radiation photometer (Carl-Zeiss, model III), previously cirawing a curve of calibration for calcium. 
The animals were killed after anaesthetisation by ether, then the adrenal gland was removed and fixed in Lison-Vokaer or Bouin fluid, and in formol + alcohol. The material was dipped in paraffin and cut into sections $6 \mu$ thick. The specimens were stained with hematoxylin-eosine, by the Azan method and Best method for revealing the presence of glycogen.

Animals in group I (control) were divided into:

$\begin{array}{ll}\text { 1. non-operated animals } & 2 \text { rats } \\ \text { 2. animals on which a blank operation was carried out } & 4 \text { rats } \\ \text { 3. animals which received intravenous injection of saline } & \\ \text { solution } & 4 \text { rats }\end{array}$

Animals in group II were divided into:

1. animals killed during 1 st week after operation 10 rats

2. animals killed within 3 weeks after operation 10 rats

3 . animals killed within 6 weeks after operation $\quad 10$ rats

Animals in group III were divided into:

1. animals killed within 24 hours after injection of sodium

2. animals killed within 48 hours after being injected twice 8 rats (every 24 hours) with sodium oxalate

\section{RESULTS}

\section{Animals in group I (control)}

Calcium level in blood serum was on average $10 \mathrm{mg} \%$.

The morphological picture of preparations from animals in the three control sub-groups did not differ from each other.

The zona glomerulosa is relatively narrow. The cylindrical cells forming this zone have fine-grained cytoplasm containing a large amount of small vacuoles. The cellular nuclei are of different sizes and shapes, with predomination of hyperchromatic nuclei. The nuclear membrane is often folded and thickened, but in certain cells the nuclei are large, vesicular, with a clearly visible chromatinous stroma. These nuclei have large nucleoles generally situated centrally.

The zona fasciculata occupies the largest part of the adrenal cortex, is wide and formed of large cells with finegrained cytoplasm delicately vacuolised, revealing very fine glycogen granular matter. The cellular nuclei are large, vesicular, with taut nuclear membrane. The delicately staining chromatin is evenly distributed. One or two large nucleoles can be observed, generally situated centrally. The blood vessels run in the connective tissue between bands of cells.

In the zona reticularis, formed of cells far smaller than the cells in the zona fasciculata, the nuclei also are smaller than those in the preceding zone. The cytoplasm of the cells in this zone is fine-grained and dense. The cellular nuclei are round and hyperchromatic with coarse-grained chromatin. The single nucleoles there are disposed centrally. The blood vessels are not congested. 


\section{Animals in group II}

1. Animals killed within one week after removal of the parathyroiid glands (calcium level in blood serum on an average $7.1 \mathrm{mg} \%$ ).

The adrenal glands of these animals have a zona glomerulosa broadeneed in comparison with that in the control animals. The cytoplasm of the cellis; forming this zone exhibits the presence of large vacuoles. The cellultar: nuclei differ in shape, with a thick cellular membrane staining intensivv-ely. Chromatin is scattered over the whole nucleus, and its thickferr granules are situated round the edge. The nucleole is situated more corr less centrally.

The zona fasciculata seems to be thinner than that in the contrrobl animals. The cells forming this zone have acidophilic and fine-graineed,, delicately vacuolised cytoplasm. The vesicular nuclei are larger than these nuclei occurring in the zona glomerulosa. Large nucleoles situated chief flyly centrally are visible in the nuclei. Enlarged blood vessels are visibblele between the bands of cells.

The zona reticularis is formed of cells smaller than those in the zonnana fasciculata. The cytoplasm of the cells forming this zone is fine-graineied.d, dense, very delicately vacuolised. The nuclei are round, hyperchromatiticic. The very numerous blood vessels are considerably enlarged.

2. Animals killed three weeks after operation (calcium level in ththe blood serum was on an average $7.5 \%$ ).

The adrenal cortex of these animals has a zona glomerulosa enlargegeged similarly to that of animals killed one week after operation. In th ththe majority of the cells forming this zone, the cytoplasm continues to $\mathrm{b} b$ be vacuolised, but cells are encountered with fine-grained cytoplasm, witliththout vacuoles. The cellular nuclei are of two kinds: dark, hyperchromatatiatic with folded nuclear membrane and light, vesicular, with a distinininct nucleole often situated near the nuclear membrane.

The zona fasciculata, in comparison with that in control animals, $h$ hi has undergone, as it were, continued narrowing. The cells forming this zozorzone are large and contain strongly vacuolised cytoplasm. The vesicular nucluclıclei are often of different size, sometimes very large and light in colour. $r$. $x$. In certain cells mitoses are visible (Fig. 1). In the majority of the nuclei ei ei in this zone, from 1 to 3 in number, large nucleoles are visible, most oftoftoften situated just by the nuclear membrane (Fig. 2). Extremely intense co co congestion is visible between the bands of cells (Fig. 3).

The zona reticularis undergoes widening in relation to that in contintintrol animals. The cytoplasm of the cells in this zone is distinctly vacuoliseiselised. The cellular nuclei are of different shapes and sizes. The exististiisting vesicular nuclei are large and light in colour with taut nuclear membra)rabrane 
and scattered fine-grained chromatin, and one or two nucleoles situated near the nuclear membrane. The blood vessels in this zone are congested with blood.

Between the zona reticularis and the medulla of the adrenal gland groups of large cells arranged side by side, forming a fourth zone of the adrenal cortex, are encountered, which were not found either in the control animals or in those killed one week after operation (Fig. 4). These cells have more acidophilic cytoplasm than other cells in the adrenal cortex. Their dimensions in comparison with the cells in the zona reticularis are almost twice larger. The cellular cytoplasm is fine-grained, dense, very delicately vacuolised. The nuclei of these cells are light. vesicular with a distinct nucleole situated mainly near the edge.

3. Animals killed within 6 weeks after operation (Calcium level in blood serum is on an average $8.1 \mathrm{ml} \%$ ).

A zona glomerulosa, narrower than in the animals killed three weeks after operation, can be observed in the adrenal cortex of these animals. It is similar in breadth to that observed in the control animals. The cells forming it have vacuolized cytoplasm. The nuclei are hyperchromatic and it is sometimes difficult to distinguish the nucleole in them.

The zona fasciculata is formed of cells reduced in size in comparison with the cells observed in the analogical zone in the third week alter operation. The cytoplasm of these cells is fine-grained, less vacuolised. The cellular chromatin is delicately scattered and in certain places near the nuclear membrane forms larger concentrations of $3-4$. The large nucleole is clearly visible, generally situated centrally. The blood vessels lying between bands of cells are only slightly congested.

The zona reticularis consists of cells far smaller than the cells in the zona fasciculata, which contains fine-grained cytoplasm. The cellular nuclei in this zone are dark, with thickened, often uneven, nuclear membrane.

Chromatin concentrated in larger clots is situated just by the nuclear membrane. In many nulei the nucleole can be seen. Unenlarged blood vessels can be seen between the cells in the zone.

Between the medulla and the zona reticularis small concentrations of cells, discribed in the animals killed the third week after operation, can be seen. These cells do not, however, form so distinctly separate a fourth zone as was the ease in the animals killed in the third week after operation.

$$
\text { Animals in group III }
$$

1. The zona glomerulosa in the animals killed within 24 hours after injection of sodium oxalate remains unenlarged in relation to that in the 
control animals. The cytoplasm of the cells in this zone is fine-grained and vacuolised. Nucleoles arranged centrally can be seen in the fairly large and vesicular cellular nuclei.

In the relatively broad zona fasciculata of this group of animals the cells have very vacuolised cytoplams. The cellular nuclei are round, light in colour, vesicular with delicately scattered chromatin, and maintain a size similar to that in zona glomerulosa. The nucleoles, from 1 to 2 in number, are situated eccentrically. The blood vessels running between the bands of cells are congested.

The zona reticularis undergoes enlargement in comparison with that in control animals, and is formed of cells with less vacuolised fine-grained cytoplasm. The cellular nuclei are vesicular, but stain fairly intensely. A large nucleole lies in the middle of the nucleus.

Between the medulla and the zona reticularis there are single cells of the fourth zone, a description of which is given for the second group.

2 . The zona glomerulosa of the adrenal cortex in animals killed 48 hours after two injections of sodium oxalate undergoes enlargement in comparison with that in the control animals. The cytoplasm of the cells forming this zone exhibits intense vacualisation. The cellular nuclei undergo enlargement. Large nucleoles lie near the nuclear membrane. Many of the cells give the impression of young cells immediately after karyokinesis.

The zona fasciculata is narrower than the analogical zone in animals killed 24 hours after the injection was made. The cells forming this zone have fine-grained cytoplasm less vacuolised than in the animals killed aiter 24 hours. The cellular nuclei are round, vesicular, with fairly thick nuclear membrane. The one or two nucleoles are most often situated eccentrically. The blood vessels in this zone undergo enlargement.

The zona reticularis undergoes considerable enlargement in relation to other zones and to the analogical zone in control animals. The cytoplasm of cells forming this zone is fine-grained and delicately vacuolised. The cellular nuclei are-smaller, and stain a darker colour. It is difficult to distinguish the nucleoles in them. The blood vessels in this zone are considerably enlarged.

Between the medulla and the zona reticularis the number of cells with acidophilic cytoplasm (fourth zone) increases in comparison with that in the adrenal glands of animals killed 24 hours after injection of sodium cxalate.

\section{DISCUSSION}

The work undertaken was aimed at finding an answer to the question as to how the cortex of the adrenal glands reacts to reduced calcium level 
in blood serum. The function of the adrenal gland has hitherto been connected chiefly with the mineral economy of sodium and potassium, little attention being paid to other cations.

In the experiments made, two groups of animals were obtained with reduced calcium level in their blood. In order to reduce the calcium level in the blood serum, the parathyroid glands were excised in one group of animals, while the other group was given sodium oxalate. In both the experimental groups similar morphological pictures, indicating the stimulation of the functioning of the adrenal cortex, were obtained. This hyperfunction was expressed by intense congestion, numerous mitoses, characteristic positioning of the nucleoles, the appearance of an additional fourth zone between the medulla and zona reticularis, and the disappearance of glycogen, which was observed only in control animals.

B o u rne (1949) in describing the adrenal glands of mammals, found that mitoses occur very rarely in the cortex of this gland. In our material numerous mitoses were found to occur in the zona fasciculata, which may be taken as a criterion of stimulation.

$\mathrm{H}$ u n t (1959) observed glycogen in the cortex of the adrenal glands of rats and stated that the slightest stimulation of this gland causes disappearance of glycogen. We also failed to find glycogen in the animals on which the experiments were carried out.

Like A I t m a n n (1955) we observed the occurrence of nucleoles often situated just near the nuclear mebrane in cells of the cortex of a stimulated adrenal gland.

The additional fourth zone of the cortex of the adrenal glands occurring in our experiments is very similar to the zone $X$ described by many authors, and many functions have been attributed to it, the views held by different authors, however, being very contradictory. Gersh \& Grollman (1939) consider zone $X$ as a reserve tissue, which is capable, when the adrenal gland is compelled to hyperfunction, of secreting additional cortical hormones. We know, however, of many experiments, consisting in the inducement of hyperfunction of the cortex of the adrenal gland, in which the appearance of an additional zone was not observed.

The presence of zone $X$ is connected chiefly with androgenic function (Grollman, 1936: Pawlikowski, 1951; Wołyńska, 1956; 'T eter, 1959).

Delost (1956), on the other hand, observed in the field mouse the presence of zone $X$ during pregnancy and lactation. As is well known, during this period there is a greater demand for calcium by the organism, anci the adrenal glands, like the parathyroid glands, exhibit symptoms of intensified function (O r łow sk i, 1957; T e ter, 1959). The appearance 
of the additional fourth zone in our experiments may therefore be evidence of intensified activity of the gland

The question then arises as to what mechanism evokes the change described above. An interesting problem here is that of whether the reduced calcium level in the blood serum acts directly on the adrenal glands, or whether it does so through the medium of other endocrinal glands, e.g. the pituitary or parathyroid glands. It would seem that the parathyroid glands should play the chief part in the disturbance of the phosphoruscalcium balance in the organism, but in the group of animals deprived of their parathyroid glands (Group II), as in the group of animals given sodium oxalate while retaining their parathyroid glands (Group III), the cortex of the adrenal glands exhibited uniform stimulation in the morphological picture. Taking these results as our basis, we can only find that that reduced calcium level goes together with intensification of function of the adrenal cortex.

It is possible that stimulation of the adrenal gland is caused by the pituitary gland (S a ki z, 1959). As reported by Jonek (1959), and by authors whom he cites, the number of cells in the peripheral part of the pituitary gland increases under the influence of acidifying substances, which causes greater secretion of $\mathrm{ACTH}$, evoking intensified activity of the cortex of the adrenal gland. It is possible that in our experiments the stimulation of the cortex of the adrenal gland which we observed occurred in this way.

The appearance of an additional fourth zone of the cortex of the adrenal gland might take place as the result of increased secretion of glucocorticoids by the stimulated zona fasciculata. Cortison may therefore exert a stimulating effect on the growth of zone $X$ (Jakowicki \& Wisniewski, 1962).

On the basis of our experimental material it is difficult to establish whether the observed stimulation of the adrenal cortex is evoked directly by the reduced calcium level in the blood serum or by intensified functioning of the pituitary gland. It would seem that this question remains an open one and needs further investigation.

\section{v. CONCLUSIONS}

1. After excision of the parathyroid glands and also after injection of sodium oxalate, reduced calcium level in the blood serum of rats and morphologica! changes in the adrenal cortex were found, indicating stimulation of cortical function (congestion, numerous mitoses, characteristic positioning of nucleoles, appearance of a fourth zone between the medulla and zona reticularis, disappearance of glycogen). 
2. The most strongly expressed changes in the adrenal cortex were observed thiree weeks after excision of the parathyroid glands and 48 hours after two injections (every 24 hours) of sodium oxalate had been given.

3. The changes observed in the adrenal cortex in both the above experimental groups did not differ from each other.

\section{REFERENCES}

1. Altmann, H. W., 1955: Zur Morphologie der Wechselwirkung von Kern und Cytoplazma. Klin. Wschr., 33, 13/14: 306-314.

2. Bens 1 y, S. H., 1947: The normal mode of secretion in the parathyroid gland of the dog. Anat. Rec., 98, 3: 361-381.

3. Bourne, G. H., 1949: The Mammalian adrenal gland. Oxford at the Clarendon Press.

4. Delost, P., 1956: La fonction sexuelle de la cortico-surrenale. Récents progrés en physiologie (par M. Bonvallet, P. Delost et al.). Publication de la Chaire de Physiologie générale de la Sorbonne, 47-74.

5. Dzierżykray-Rogalska, I, 1958: Badania doświadczalne nad przytarczycą szczura bialego. Folia morphol., 9: 333-338.

6. Eg e r, W., 1953: Ein Beitrag über Bezichungen der chronischen Niereninsuffizienz zu innersekretorischen Drüsen an Hand experimenteller Untersuchungen. Klin. Wschr., 31: 409-417.

7. Eppinger, H., Falta, W., \& Rudinger, C., 1908: Uber die Wechselwirkungen der Drüsen mit innerer Secretion. Ztsch. Klin. Med., 66, 1: 1-52.

8. Forsham, P. H., 1963: The adrenal gland. Ciba Corporation USA, 1-20.

9. Gersh, I., Grol1man, A., 1939: Anat. Rev., 75: 131. (Acc. to Bourne, 1949, pp. 205-206).

10. Groll ma n, A., 1936: The Adrenals. Baltimore.

11. Gulecke, W., 1911: Experimentelle Untersuchungen über Tetanie. Arch. Klin. Chir., 94, 3: 496-532.

12. Harrop, G. A., Soffer, L. J., Read Ellsworth \& Trescher, I. H. P., 1933: Studies on the suprarenalcortex. III. Plasma electrolytes and electrolyte excretion during suprarenal insufficiency in the dog. J. Exper. Med., 58, 1: $17-38$.

13. Hunt, T. E., \& Hunt, E. A., 1959: Glycogen in the adrenal gland of rats at different ages. Anat. Rec., 133, 3: 537-551.

14. Jakowicki, J. \& Wiśniewski, L., 1962: Badania chemiczne i histochemiczne nad warstwą X u myszy białych. Endokr. pol., 13: 257-265.

15. Jonek, J., 1961: Wplyw kwasu glutaminowego i innych substancji zakwaszających na obraz histochemiczny gruczołów dokrewnych królic (nadnercza). Endokr. pol., 12; 279-289.

16. Kis c h, B., 1924: Experimentale Untersuchungen über die Function der Nebennieren. Klin. Wschr., 3, 37: 1661-1663.

17. Menozzi, P. G., Biggi, S., Cacioppo, A., \& Gat to, E., 1961: Endocrine glands and bone. II. Biochemical and histomorphological bone tissue alternation after cortisol treatment. Arch. E. Maragliano Pat. Clin., 17, 6: 1125-1138. (Acc. to Exc. Med., Sec. 1, 1963, 17. p. 221).

18. Or lowski, W., 1957: Nauka o chorobach wewnętrznych. 8. Gruczoly wydzielania wewnętrznego. PZWL, Warszawa.

19. Pawlik owski, T., 1951: Pozaplodowy rozwój nadnercza u czlowieka. Endokr. pol., 2: 185-191. 
20. Rog off, I. M. \& Steward, G. N., 1928: Studies on adrenal insufficiency:y. VII. Further blood studies (cholesterol and calcium) in control of adrenalecto-0mized dogs. Am. J. Physiol, 86, 1: 25-31.

21. Rohdenburg, G. L. \& Krehbie 1, A., 1925: On the relation of certainin endocrines to the saltcontent of rat blood. J. Cancer Res., 9, 3: 422-424.

22. Sakiz, E., 1959: Action sur la zona X surrenalienne de la souris, de la corti-icostimuline on d'une agression. C. R. Soc. Biol., 153, 3: 405-410.

23. Sa 11 is, J. D. \& Holdsworth, E. S., 1962; Calcium metabolism in relationn to vitamin $\mathrm{D}_{3}$ and adrenal function in the chick. Am. J. Physiol, 203, 33 : $506--512$.

24. T a y $1 \circ$ r, N. B. \& C a v e n, W. R., 1927: Observations upon the serum calciurm after adrenalectomy. Am. J. Physiol., 81, 2: 511-512.

25. Teter, J., 1959: Zaburzenia hormonalne u kobiety. PZWL, Warszawa.

- 26. W ołyńska, M., 1956: Rozwój płodowy nadnercza człowieka. Folia morphol.1., 7: $35-51$.

Białystok Medical Academy,

Department of Histology and Embriology,

Białystok, ul, Kilińskiego 1.

\section{STRESZCZENIE}

Autorzy badali metodami histomorfologicznymi zachowanie się kory nadnerczyy u szczura białego przy obniżonym poziomie wapnia w surowicy krwi. Poziom wapnida obniżano jednej grupie zwierząt przez operacyjne usunięcie przytarczyc, drugie,ej natomiast przez wstrzykiwanie 0,1 M. roztworu szczawianu sodu. Kora nadnerczy. obu grup doświadezalnych wykazywała objawy pobudzenia. Autorzy dyskutują naad mechanizmem mogącym wywoływać wzmożenie czynności kory nadnerczy. Rozpa-1trują drogę bezpośredniego działania obniżonego poziomu wapnia na korę nadner-tczy oraz drogę pośredniego działania poprzez przysadkę mózgową i przytarczycęę. Badany materiał doświadczalny nie pozwolił na stwierdzenie bezpośredniej zależzności przytarczyc i kory nadnerczy. Powiązanie obserwowanej nadczynności koryy l'adnerczy z przysadką mózgową wydaje się być prawdopodobne, jednakże zagad-lnienie to pozostaje nadal otwarte i wymaga dalszych badań.

\section{EXPLANATION OF PLATES}

Plate XIV.

Fig. 1. Mitosis in the cells of zona fasciculata (animal killed three weeks afterr excision of the parathyroid glands). Magn. 2300 $\times$.

Fig. 2. 1-2 nucleoles situated near the nuclear membrane in cells of zona fasciculata (animal killed three weeks after operation). Magn. $1400 \times$.

Plate XV.

Fig. 3. Intense congestion of the adrenal cortex (animal killed three weeks afterr operation). Magn. $470 \times$.

Fig. 4. Cells in the fourth zone situated between the medulla and zona reticulariss of the adrenal cortex (animal killed three weeks after operation). Magn. $345 \times$. 

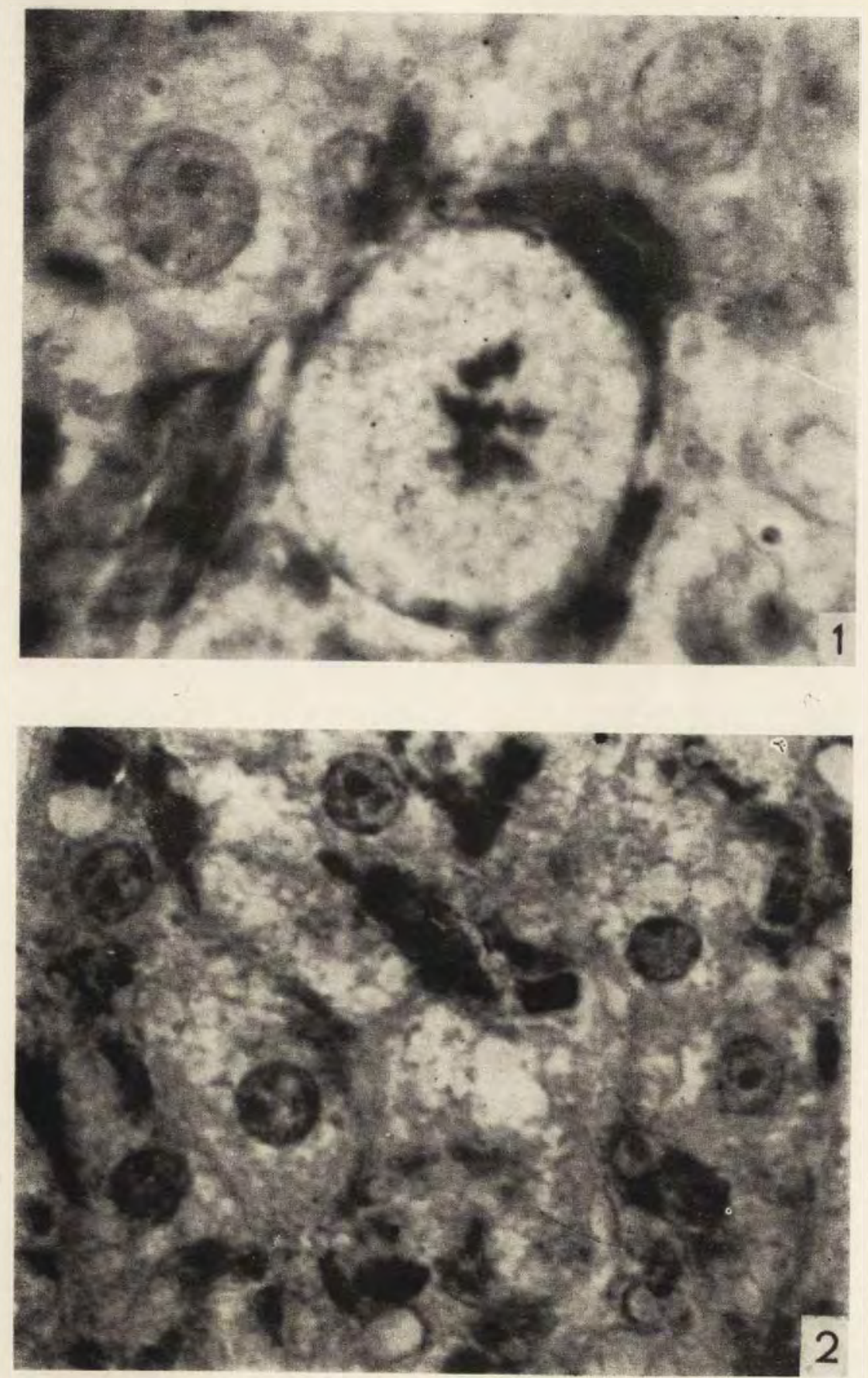

I. Dzierżykray-Rogalska \& A. Serwatko

auctores phot. 

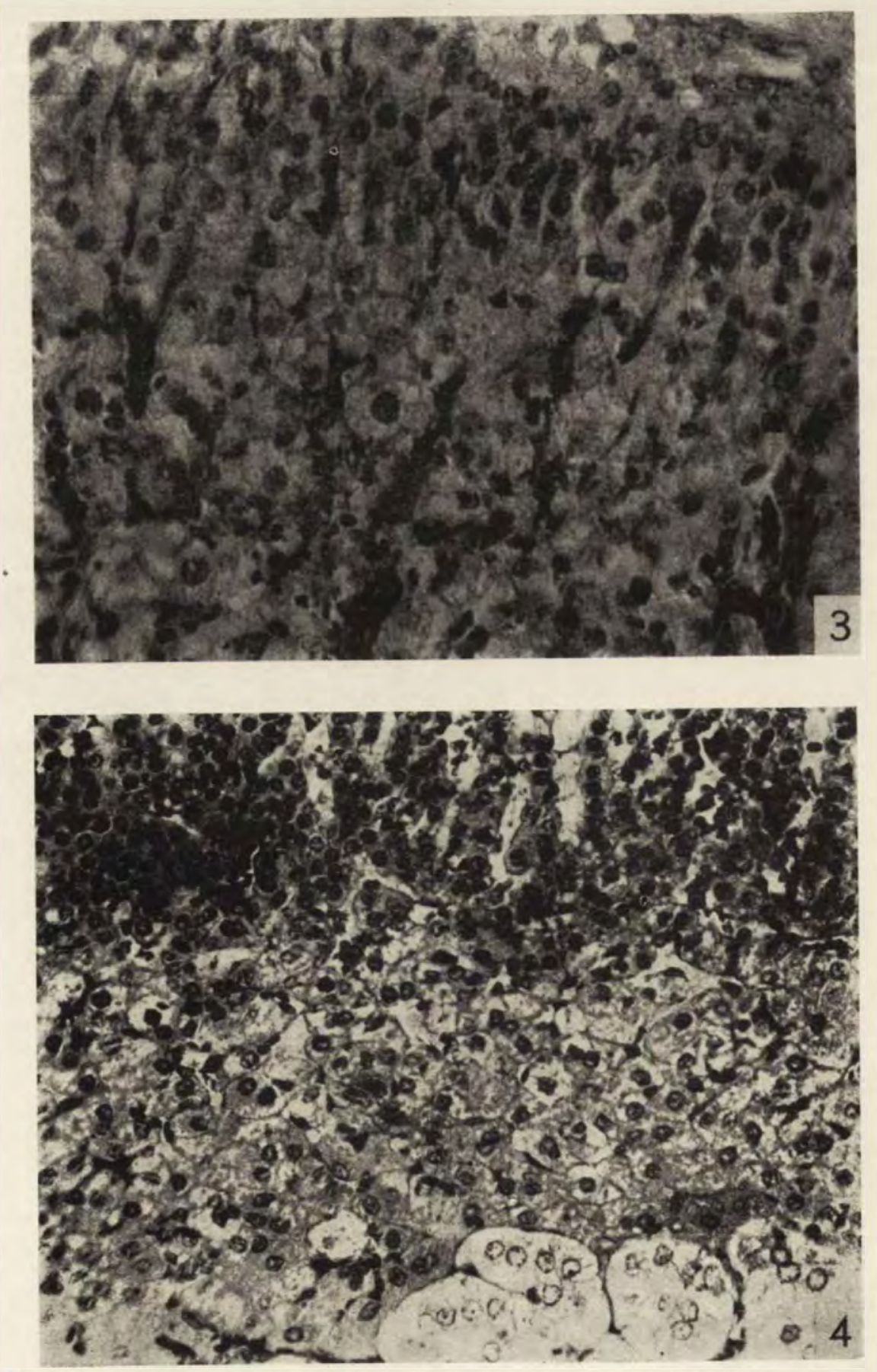

I. Dzierżykray-Rogalska \& A. Serwatko 